\title{
Research on the Problems of Higher Education Foundation in China Based on Triangle Coordinated Mode
}

\author{
Ling Xie \\ The Education Institute \\ Xiamen University \\ Xiamen, Fujian, China 361005
}

\begin{abstract}
The higher education of our country has stepped into the later period of popularization followed by increasingly large amount of expenses required for education development. In addition, confronted with the gradually severer background of international competition, the amount of expense input of education and research development has become the principal restricting factor to promote higher education competitive capacity. Besides, as a vital educational financial resource selfraised by universities and colleges, the higher education foundation has attracted more and more attentions from scholars; meanwhile, the colleges and universities of our country have set their respective higher education foundation in succession. However, due to its rather later start, a lot of problems emerge in the property and status, investment operation, donation management and popularizing, and the role of higher education foundation in providing financial resources of colleges and universities have not been played well.
\end{abstract}

Keywords - education foundation of higher education; triangle coordinated mode; research of problem

\section{INTRODUCTION}

Foundation, such non-government and non-profit organizations, is operated and managed by its trustee or the board of directors as planned on work and with its independent funds, is aimed at supporting or assisting education, charity and other public welfare establishments. In accordance with the definition of Article II of Regulations on Administration of Foundations passed by the State Council on the 39th conference held on February 11, 2004: "the foundation mentioned in this article, refers to any non-profit corporate established as per stipulations of the Regulation and utilizing the properties donated by natural persons, legal persons or other organizations, for contributing to public welfare undertakings." Furthermore, an education foundation of universities and colleges, as one sort of Non-Profit Organization - foundation, is initiated and founded by a university or college, with schools as the service object, and is mainly designed to raise funds from all sectors of society and receive donations for carrying out schools' activities instead of profiting. Moreover, as one kind of diversified foundations, the education foundation of universities and colleges, a newborn thing occurring in a relatively uncertain period, can increase the financial liquidity and build a closer link between schools and society; On the other hand, sufficient funds also are beneficial to the improvement of education quality. As a result, it is capable of motivating the further development of universities and colleges. The collection is oriented to special objects, for example specific persons or organizations instead of every social citizen, so essentially it belongs to non-public foundation.

In general, the education foundation of universities and colleges only donates for public welfare establishments related to higher education, and at the same time only receives charitable donations from inside and outside schools. In addition, it has no direct connection with the school management and scientific researches and only takes charge of the management and distribution of donated funds, specifically, attending fund distribution to departments, faculties and each project of teachers etc., providing guidance and advice and supervising the use of funds.

The education foundation of universities and colleges in our country is founded in accordance with the Regulations on Administration of Foundations, and can raise fund by legal channels and provide fund supports through operation and management of maintaining and increasing the fund value, so as to drive and promote the development of national higher education career. Despite of the objective of subsidizing the development of higher education, as an independent legal entity, it belongs to operation-type non-public offering foundation.

\section{FUNCTIONS OF EDUCATION FOUNDATION OF UNIVERSITIES AND COLLEGES}

\section{A. Relieve the National Financial Pressure; Enhance the} Financial Autonomy of Colleges and Universities.

According to the American economist Johnstone, the costs for higher education must be shared by multi-directional resources including parents, students, government, taxpayers and colleges \& universities no matter which sort of society, regime and country. Based on the education cost sharing principle, it also indicates that the costs for higher education require to be jointly assumed by government, society, 
enterprise, individual and family under reasonable allocation. However, in our country, above a half of higher education comes origins from fiscal educational allocate funds of the state. In the wake of rapid development and double first-class construction of higher educational business, excessively relying on the state fiscal allocations is certainly insufficient to satisfy the demands of higher education development. Therefore, the education foundation of colleges and universities, as a fund-raising institution, has a increasingly prominent status and gradually manifests its importance in, besides of relieving the national financial pressure, strengthening financial autonomy of universities and colleges to a great extent with strong fund raising capacity and large sum of amount, further to gain more right of speech in many aspects such as teaching and scientific research, improvement of facilities construction and services for students as well as reform of school governance model etc.;

\section{B. Attract Social Wealth and Resources; Increase School Income; Enhance the Links between the Society and School}

The dramatic growth of the national economy has accumulated a plentiful of idle capital in the society, in addition to the liveliness of private enterprises and increases of multinational companies bring more developing space for philanthropy of our country. By raising funds from the society via education foundations, this country figures out a way to more than sharing the increasing higher educational expenses and to strengthening the connections between colleges and society by the close bond - educational foundations. Moreover, it is an inevitable direction that the educational appropriations will gradually no longer be primarily borne by governments but manifest a diversified development, and college educational funds are one of the means to link colleges and markets together. Referring to some foreign experience, pluralism of educational financial resources is certain to significantly change revenue structure of colleges, which commonly embodies on decrease of government allocation proportion along with a rise of self-financing. Since the 1990s, the US government has been gradually cutting down the appropriation amount for public institutions of higher learning following, on the opposite, an ever-increasing proportion of donation accounting for the annual aggregate investment. A large proportion of incomes of private universities of the United Sates are from donations of school mates and society, which is the result of American laws that consistently encourage social donations. So far the national planning appropriation for higher education can only maintain the daily expenses, and in case of any intentions to development, schools have to strive for funds relying on their own strengths. It is said that for some domestic universities, for example, Beijing University, the national fiscal appropriation can only satisfy its $1 / 3$ of expenditure requirement, and the rest requires acquiring upon the school strengths.
C. The Education Foundations of Universities and Colleges Are Capable of Realizing Appreciation and Hedging of Capitals and Enhancing the Ability to Financial Crises Resistance by Investment Operation

In other words, the foundations is dedicated to, by means of raise, operation and investment of funds, guaranteeing the appreciation and hedging of funds so as to maintain the vitality of foundations, for life force of foundation consisting in fund operation. Furthermore, investing and operating educational foundation market can enhance the financial ability and strengthen the capability to withstanding financial crises of schools. Only a few of domestic universities have developed relatively mature educational foundations, such as Tsinghua University and Zhejiang University that have obtained increase in value by regulation of assets and stocks via national debt and entrusted security companies, or by profiting from the operation of internal virtual settlement centers, or by the fund classification and management. However, for the foundations of most universities, such as Xiamen University, the primary incomes are still from external donations, and the fund appreciation can only be realized by deposit in banks to generate interests, which greatly limits the fund appreciation and restricts the development of foundations.

\section{Integrate Resources to Support School Development}

The education foundations of universities and colleges can integrate labor and material resources of colleges to support the developing emphases and further shape a sound resource integration pattern/mechanism with distinct advantages, not only in utilizing donations but raising donations from people from all circles and social organizations, and by taking full advantage of those effective resources and formulating reasonable system of resource integration where is, for example, demand-oriented, project-driven to realize rational allocation of depletable resources and optimized integration so as to preferably construct and develop the foundations. With the purpose of fulfilling great-leap-forward development of colleges, it is required to, according to the proposed development objective, deploy all available strengths and optimally utilize various resources. The past poor performances on strategic development of universities is because that the improvement and growth of a university still requires depending on both external supports and internal strengths that can only be developed by advancing its construction level. And now, education foundations of universities and colleges have become one of such resource optimization and integration system.

\section{E. Accelerate the Scientific Management of Universities Themselves.}

It means to convert development strategy of a university to the specific manifestation in system established for governance Nothing but through innovation and reform to abandon the old ideas and systems, can new policies suitable for the development requirements of schools be set out to lay a solid foundation for realizing the goal of increasing strategic development ability of schools. In addition, in order to guarantee the normal operation of colleges, it must set up a high-level administrative service system to consciously 
organize a reform of internal organizational structure, in spite of increasingly complex internal and external affairs of schools. Any internal behaviors, including operation, management, and supervision of the third party, evaluation and incentive policies etc. of a education foundations of universities and colleges are non-profit, which decides that the foundation organization is a relatively independent and flexible system. Its normative development and institutional improvement enlightens the organizational reform acts of colleges and universities to improve their quality and level of education.

\section{F. Cultivate the Consciousness of Responsibility of Citizens and Provide Them with Approaches to Attending Public Welfare Establishments.}

In America, donating colleges and universities has become a fine tradition; while the situation is quite gloomy in our country. Therefore, it is necessary to facilitate social elites to donate colleges by virtue of efforts of schools and various parties and to foster the awareness of social responsibility of citizens to a certain extent. By promoting moral construction of citizens, accelerate the formation of good social custom. Besides, foundations have tremendously motivate the enthusiasm of citizens to donate educational business and provide voluntary services, and the superficial enthusiasm finally internalizes and deposits to a moral accomplishment of mutual help to accelerate the formation of good social custom.

\section{SumMARY ON TRIANGLE COORDINATED MODE}

\section{A. Summary on "Triangle Coordinated Mode" of Burton Clark}

Burton R. Clark has analyzed the law of higher education operation from the perspective of academic organizations of higher education system in his classic The Higher Education System - Academic Organization in Cross-National Perspective, and held the idea that departments and colleges are the basic units of institutions of higher learning and can form a complicated academic system through the coordination of the nation, market and scholars. The tasks of higher education increase sharply and various beliefs of and powers draw it towards diverged directions; besides, all kinds of state powers including bureaucracy, politics and academic authorities take their participation in the integration of higher education system. Burton Clark has established three ideal types - state system, market system and major system, and focused on analyzing the combination of the state and market, in addition to the discussion on the important issue - the limits of state control. With the infinitely increasing of academic authorities and raising of potential activities, Clark readjusts the continuous body from state power to market function to the triangular coordinating mode among the state, market and academic authorities, as Fig.1.

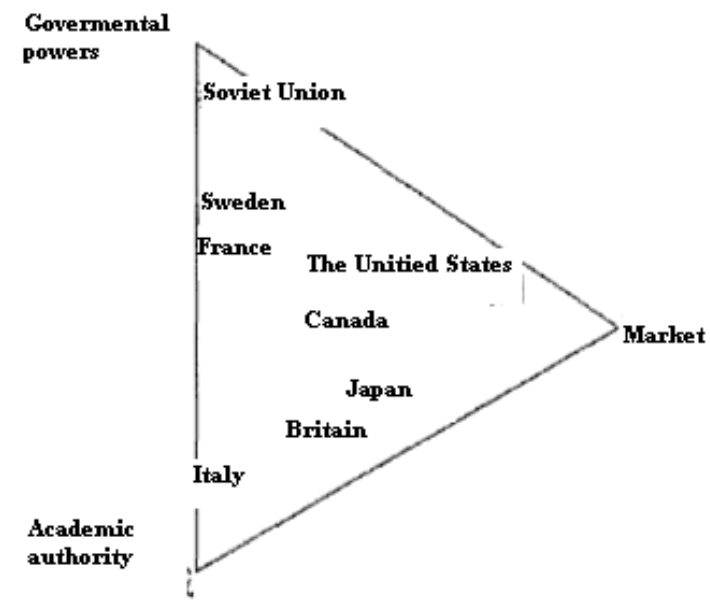

Fig. 1. Triangle coordinated mode of higher education

In the light of Burton Clerk, the ideal mode is that governmental powers, academic authority and market are in tripartite balance of forces and mutual exclusion and containment. In this "triangle", governmental powers stand for collective wills of the society that cast its influences on the higher education system through laws, policies and appropriations etc.; academic authority comes from instinct strengths of knowledge and professions carried by senior professors, experts and scholars that can exert its impacts on the education development by normal organizations (such as various academic committees) and informal channels; while market mentioned here indicates the intentions of education customers or the requirements of service objects of higher education and receivers of products. It is pointed out by Clark that the development of higher education in different countries shows diversified tendencies, and provided that a country decides to supply most even all required expenses for higher education developing, the government powers (state) to control higher education will be elevated; conversely in the event of the subject held by the market or other non-government roles, the government powers (state) to control higher education will be weakened comparatively.

\section{B. Analysis of the Feasibility of Education Foundations of Universities and Colleges Based on "Triangle Coordinated Mode"}

At first, from the point of view of system theory, "triangle coordinated mode" is propitious to analyzing the issues on education foundations of universities and colleges, as stated in The Higher Education System - Academic Organization in Cross-National Perspective of Burton Clark, higher education is referred to as a system with three elements: "knowledge, belief and power" under a harmonious interaction to mutually facilitate the development of higher education. Besides the original purpose of "triangle coordinated mode" lying in studying on the relations between universities and other external systems, the higher education system has become an organic subsystem of the entire social system, and increasingly depends on the coordinative functions of government acting in various subsystems so as to guarantee the normalization of education resource supply; on the other hand, the regulating 
effects of market have turned to be an essential external environment for the existence and development of universities. The system theory emphasizes globality, relevance, grade structure, dynamical balance and time sequence etc. which are also raised as the basic ideas and fundamental principles of system approach. The core idea of system theory is based on the concept of entirety and system; proceeding from the entirety, institutions of higher learning are a subsystem subsidiary to the superior system of social environment and it has its own interior structure with subunits like education foundations of universities and colleges; that is say, the foundations themselves, are a product of game among government, market and university, therefore the author believes the education foundations of universities and colleges, in essence, are also under the balance and restriction of university, market and government.

Shifting the perspective to interested parties, the multiangular issues of college education foundations creates the breeding ground for applying "triangle coordinated mode" to solve those issues related to foundations. According to the theory of interested parties, modern organizations including public institutions of higher learning contain various interest relations, concerning colleges themselves, banks, government and education authorities of government, local governments, students and the public. In other words, public colleges serve people, instead of government or an individual student, so constructing and developing public colleges should not be exclusively undertaken by the government but should meet the requirements of both society and market, and accord with both benefits of students and all other interested parties. The issues on education foundations of universities and colleges are concerned with colleges and universities, government, banks, donors from society and market operators of foundations etc., and considering the demands for realistic benefits of colleges and universities in our country, the interested parties mainly include competent departments of government, donors of foundation, students of colleges and competitors of colleges, market operators of education foundations of universities and colleges and enterprises investing in foundations and so on all of whom can be divided into three parties: government, colleges and market.

\section{Under THE TRIANGLE COORDINATION MODE THE ANALYSIS OF DEVELOPMENT PROBLEMS OF CHINA'S EDUCATION FOUNDATIONS}

\section{A. The General Overview of Development of China's Education Foundations}

From the data published by the central nets of foundations, it's known that from 1994 when the education foundation of Tsinghua University was formally registered to March, 2016, at present there have been 503 university and college foundations, and in recent 10 years the number of foundations is increased by no less than $20 \%$ per year, and the increase of the number of China's education foundations is very rapid; for total assets, at the end of 2014, the net assets of China's education foundations reached 26.25 billion, accounting for $24.9 \%$ of the net assets of China's all foundations. Generally speaking, China's education foundations of universities and colleges developed rapidly in number and to total net assets.

But the proportion of total assets in funds income of college education is still low, and according to Table 1 cleared up from the data of China Educational Finance Statistics Yearbook of 2014, in the educational finance income of 2014 for national institutions (including general institutes of higher education, higher undergraduate universities \& colleges and vocational colleges) of higher learning in 2014, incomes from social donation and undertaking revenue except tuition totally only account for $14.13 \%$ of total income, of which income from social donation only accounts for $0.53 \%$, while national fiscal expenditure of education (whether needing explaining its composition) accounts for $60.3 \%$. Thus it can be seen that China's current income from higher education funds unduly relies on national finance and self financing ability needs to be enhanced.

TABLE 1 INCOME SITUATION OF UNIVERSITIES AND COLLEGES’ EDUCATIONAL FUND IN 2014 UNIT: THOUSAND RMB

\begin{tabular}{|c|c|c|c|c|c|c|c|}
\hline School type & Total & $\begin{array}{c}\text { State fiscal } \\
\text { expenditure of } \\
\text { education }\end{array}$ & $\begin{array}{c}\text { Investment of } \\
\text { organizers in } \\
\text { non-state-run } \\
\text { school }\end{array}$ & $\begin{array}{c}\text { Social } \\
\text { Donation } \\
\text { Expenditure }\end{array}$ & $\begin{array}{c}\text { Undertak } \\
\text { ing } \\
\text { Revenue }\end{array}$ & $\begin{array}{c}\text { Tuition and } \\
\text { fees }\end{array}$ & $\begin{array}{c}\text { Other } \\
\text { revenue }\end{array}$ \\
\hline $\begin{array}{l}\text { Institution of } \\
\text { higher }\end{array}$ & 817861475 & $\begin{array}{l}493339068 \\
(60.3 \%)\end{array}$ & $\begin{array}{l}3403222 \\
(0.42 \%)\end{array}$ & $\begin{array}{l}4359056 \\
(0.53 \%)\end{array}$ & $\begin{array}{l}69792832 \\
(8.5 \%)\end{array}$ & $\begin{array}{l}204839432 \\
(25.1 \%)\end{array}$ & $\begin{array}{l}42127865 \\
(5.2 \%)\end{array}$ \\
\hline
\end{tabular}

Data source : China Educational Finance Statistics Yearbook of 2014

The income channel of China's university and college education foundation is relatively simplex, and the investment efficiency is relatively low. China's current incomes from university and college education foundation mainly rely on the donation of schoolfellows; and for investment operation, most of university and college education foundations are mainly the management of book cash flow and deposit in bank \& common wealth, and although some universities and colleges involve the investment of stocks and bonds, most of universities and colleges worry that their investment risk are too high and still not activate the investment of negotiable securities. The Development Tendency Analysis of Universities and Colleges Foundation 2011-Edition published by central net of foundations mainly divide the income of universities and colleges foundations into four parts, which are donation income, investment income, service income, and other incomes. In 2010, 94\% of the income of China's income of university and college foundations is from donation income, and of which, $87 \%$ is from domestic income, and just $5 \%$ is from investment income. 
TABLE 2 THE TOTAL COMPOSITION OF INCOME OF UNIVERSITIES' FOUNDATIONS IN 2010, (UNIT: YUAN)

\begin{tabular}{lll}
\hline $\begin{array}{c}\text { Total composition of } \\
\text { income }\end{array}$ & \multicolumn{1}{c}{ Amount } & Proportion (\%) \\
\hline General income & $4,656,480,396.54$ \\
Donation income & $4,387,028,874.02$ \\
Investment income & $220,277,307.45$ \\
Other income & $36,442,526.26$ & \\
\hline \multicolumn{2}{c}{ Data resource: Data center of Foundation Center, and the expiration date is December 31, 2010 }
\end{tabular}

TABLE 3 THE DONATION COMPOSITION OF INCOME FOR UNIVERSITY AND COLLEGE FOUNDATIONS IN 2010 (UNIT: YUAN)

\begin{tabular}{lll}
\hline \multicolumn{1}{c}{$\begin{array}{c}\text { Constitution of } \\
\text { donation income }\end{array}$} & \multicolumn{1}{c}{ Amount } & Proportion \\
\hline Donation income & $4.387,028,874.02$ & 100 \\
In China & $3,822,708,552.76$ & 87 \\
Nature person in China & $1,915,105,653.50$ & 44 \\
Legal person in China & $1,907,602,899.19$ & 43 \\
Out of China & $564,320,321.40$ & 13 \\
Nature person out of & $216,168,402.92$ & 5 \\
China & & 8 \\
Legal person out of & $348,151,918.44$ & \\
China & \\
\hline Data resource: Data center of Foundation Center, and the expiration date is December 31, 2010
\end{tabular}

In general, in recent years the development of China's university and college education foundations is very rapid, especially the number of education foundations and total assets increase rapidly. However, for the function of university and college education foundations, compared with foreign university and college foundations, many problems such as the proportion of income of colleges and universities is relatively low, the channel of foundation income is simplex, and the income from investment is relatively few still exist in China's university and college education foundations.

\section{B. Problem Analysis of China's Education Foundations of Universities and Colleges Under Triangle Coordination Mode".}

1) Organization structure: The over-involvement of governments and universities \& colleges and too strong administrative intervention. Theoretically, according to the provisions of Regulations on Administrations for Foundations, education foundation of university and college refers to nonprofit legal person using property donated by natural person, legal person or other organizations for the purpose of public welfare establishments. However, in reality, for organization structure, China's education foundation of university and college is affiliated with a university or college; it can even say it is a functional department of university or college with relatively deep political complexion. Looked from the current situation, in most of China's universities or colleges the education foundation is subordinate to functional departments of universities or colleges like university or college development office, and some foundations, which are established as secondary units of universities or colleges like other departments, commonly work in one office with units like alumni association, and meantime the setting of inner organizations of foundations varies in different universities or colleges, but most of them set board of directors and secretariat, and according to the difference of self-condition of universities or colleges set different business departments.
Looked from the internal and external organization structure of education foundations of universities or colleges, China's foundations are independent legal entities, but because the restrictions on powers and functions by governments, universities and colleges are too strict, the functions are still traditional administrative functions. During concrete operation, the effective incentive system are not easily formed to recruit and take in excellent talents, which leads to the scales of education foundations of China's universities and colleges are relatively small, and the donation appeal of society is relatively small, lacking enough assets to conduct investment operation and the relevant effects don't appear easily.

2) Management team: The management system is ambiguous and the motivation of staff lacks the drive of market competition mechanism. Fund management team involves in the recruitment, remuneration, promotion and training system of employees. At present the number of employees for education foundations of China's universities or colleges is small, and their degree of specification is not high who mainly come from the recruit \& selection or the addition post of universities or colleges' administrative posts whose management mode is administrative management where corresponding systems have not been established. The investment operators for education foundations of universities or colleges are often staff of universities or colleges whose salaries are given out in accordance with the salary standard of general administrative staff of universities or colleges, and the income from investment of investment operator has no direct connection with the personal salary, and by reason of it, most of education foundations of universities or colleges cannot easily recruit professional fund investors let alone establish a specialized investment team. With the development of China's education foundations of universities and colleges, a part of foundations have established corresponding incentive system, but the goal-oriented of the incentive system in the foundations In general, for the incentive objects in education foundations of universities and colleges there are different kinds of staff. The first kind is ordinary personnel at secretariat whose job content is relatively simplex and has no direct connections with the decision-making and implementation of capital investment. The other kind is full-time investment and operation people who are mainly responsible for fund investment and operation of foundations of universities and colleges with relatively strong power of work. The two kinds of personnel shall be differentiated from the incentive mechanism design, but at present even there are universities and colleges with corresponding incentive system, but their pertinence of classification motivation is relatively weak.

For the recruit \& selection, promotion and salary of management team of education foundations of universities and colleges, specific systems have not been established by China's universities \& colleges and relevant departments of governments, which specify the delineation of power of universities \& colleges, governments and markets in the management team for education fund of universities and colleges. The management team for education foundations of universities and colleges lacks effective incentive mechanism and the professional talents of capital investment and operation, 
and the salary and promotion don't link up with the actual work performance.

3) Cost expenditure: The policies and regulations are rigorous, the cost expenditure is too low, and the development of education foundations of universities and colleges is restricted. For the education foundation of universities and colleges, as a non-profit organization, its aim is not to make profit so it cannot use money from donation to "do its own thing", but not permitted to "seek personal gains" doesn't mean not producing relevant expense and cannot mean free service, because for the public welfare institutions, a large amount of money shall be needed for the scheme and implementation in addition to the development of each activity, and administrative expenditures like manpower and material resources also need to be put into in the development of programs, which is also the expenditure of "operating capital". In China, the government and society strictly restrict the operating cost of public welfare institutions all the time. In the regulation of Article 9 of Regulations on Funds issued and put into force by the State Council in 1998, salaries and office expenses of staff of foundations are paid in income like interest of funds, and according to the regulation, the administrative management costs of public interest organizations can only be obtained from income like interest, and cannot be directly obtained from donation, which means if the income like interest of a public interest organization doesn't reach a certain amount, the organization will inevitably get into the financial crisis. In Article 29 of Regulations on Funds issued in March 2004, specifying the minimum proportion of annual public welfare expenditure of foundations: "expenditures of programs for public good used in regulations by public-raising foundations shall not be less than $70 \%$ of the general income of previous year; expenditures of programs for pubic good used in regulations by non-public foundations every year shall not be less than $8 \%$ of the fund balance of previous year, and wages \& welfare of staff of foundations and expenses of administrative office shall not exceed $10 \%$ of total expenditure of current year. For these numbers, the official statement is "increase the fund efficiency of foundations, facilitate the foundations to downsize organizations and personnel to increase the efficiency of work." This statement is made which aims at the situation that some employees from a part of foundations just get salaries but don't do actual things. Under harsh terms, the majority of domestic foundations have to be stuck in the status of "low cost" or "zero cost" operation, which heavily affected the development and promotion of public benefit activities; in addition, on the one hand, low operational costs and expenses, to a certain degree, means a denial and un-satisfaction to the performance of management personnel; on the other hand, education foundations of colleges and universities are lack of funds for publicity and advertising further to build strong management teams and attract donators; therefore, it is quite difficult for the domestic foundations to drastically expand the scale.

4) Investment and operation: The investment channel is simplex, and the market participation is not high, and the appreciation of education foundations of universities and colleges is not realized. The investment of education foundations of western universities and colleges widely involves many fields such as stock, bond, real estate, and private equity, and the investment income has accounted for the vast majority of the total income of foundations. A part of China's education foundations of universities and colleges have started to invest, and a small part of universities and colleges have set foot in field such as national debt, corporate bond, convertible bond, and a very few universities and colleges invest in stock market, but the number of them is very small, and their investment methods are too simplex and the rate of return is extremely low. The market participation of China's education foundation is too low, lacking market operation ability. In investment operation undefined investment objectives, indistinct investment strategies appear easily and in investment operation the risks and earnings cannot be combined well, especially the more less the capital scale of the education foundation of university or college is, the more attention will be put into the avoidance of risks by them, and even some education foundations of colleges and universities think "without the precedents and support of leaders, we dare not carry out investment", " the investment risk is too high, we dare not invest". These investment operation concepts will result in the capital operation of most of China's education foundations of universities and colleges are depositing and purchasing bonds-based. During the time of inflation, this kind of action of investment operation not only cannot realize the appreciation of education fund, even lead to the appearance of situation of the continuous devaluation of assets.

\section{DEVELOPMENT PATH ANALYSIS FOR EDUCATION FOUNDATIONS OF UNIVERSITIES AND COLLEGES BASED ON "TRIANGLE COORDINATION MODE.}

\section{A. The Government}

To improve relevant legal system, assure limits of authority for government, universities \& colleges, and markets, and establish effective social incentive mechanism. In accordance with the current development tendency of China's education foundations of universities and colleges, the government shall as soon as possible set about establishing a relatively complete set of legal system for non-profit fund especially for the management of education fund to safeguard the legitimate interest of education foundations and there are laws to abide by and the operation is standardized and orderly during the development of activities by education foundations, and meantime the government, in due time, can consider adding inheritance tax and resource tax, strengthen the levy of inheritance tax , improve the tax relief system, gradually intensify the progressive dynamics for tax rate of individual income tax, adjust the gap between the rich and the poor in society, and motivate the heritage donation and personal income donation; in the meanwhile, according to actual needs, the government simplify the procedures for examination and approval about pre-tax deduction to provide a good policy environment for public welfare donation. In addition, it's necessary to conduct preferential policy, and guide and increase the publicity for public opinion. Education fund belongs to work for the public good so government departments at all levels shall give it support and encouragement, provide a good surrounding for it. Each 
foundation and relevant education sector especially social media shall actively develop promotion; facilitate people's recognition and understanding of the work of education foundation to enlarge the influence of education foundation and make efforts to create development environment and donation atmosphere for foundation with wide support from society.

\section{B. Universities and Colleges}

1) Through the reconstruction of organization structure, strengthen the dominant position of investment management for education foundations: In terms of the level of universities and colleges, In order to enhance the investment operation ability of education foundations for universities and colleges, at first the organization structure of foundations should be changed especially the position of investment subject of foundations should be strengthened. Due to the difference of scale of China's various education foundations of universities and colleges and the difference of investment operation abilities, every university and college actively explores the organizational management structure which is suitable for the development of foundations by combining with selfcharacteristics especially the setting of foundations for wellknown foreign universities and colleges can be used for reference. For example, Harvard University and Stanford University break the restriction on investment operation of foundations brought by structural organization through establishing independent companies for investment management and realize the good operation of foundations of universities and colleges; the patterns where committees for investment management manage and appoint chief investment officer to take charge of investment affairs represented by Yale University and Oxford University. However, no matter what kind of pattern, it's required that the existing organizational structure for China's education foundations of universities and universities should be reconstructed to highlight the dominant position of investment management for education foundations of universities and colleges.

2) Establish incentive mechanism and attract excellent talents for professional investment and operation: The investment operation of education foundations of universities and colleges must employ excellent talents for professional investment and operation. For example, in 1985, Yale University employed David Swenson to be in control of the operation of his foundation, and in 2013 the asset scale of foundation of Yale University reached 20.7 billion US dollars, whose achievement is inseparable from employing David Swenson. Certainly, through the reconstruction of the abovementioned organizational structure, the restriction of past salary structure for education foundations of universities and colleges can be changed, and by means of using incentive salary system, establish performance system, construct longterm motivation mechanism and attract excellent talents, so for the development of China's education foundations of universities and colleges, incentive salary and performance system are adopted to attract talents for professional investment.

\section{Market}

To assure investment goals, optimize investment strategies and expand investment channels. Generally speaking, in investment operation, the investment goals established by education foundations of universities and colleges can be divided into three levels: at first within the acceptable risk range, the maximum long-term total return; second, on the premise of long-term break even, gain the reasonable and predictable income; at last, in the case of minimum risk, maintain and increase the actual value of capital. Under the guidance of investment operation and objective, China's education foundation of universities and colleges should formulate effective investment strategies and expand investment channels in accordance with the current circumstances for investment market in China, which, concretely speaking, can be implemented from the following three aspects: at first, foundations may reduce the proportion of cash holdings, and properly increase the proportion of negotiable securities like bond and stock, and may also increase the profit of current capital under the condition of minimum risk by P2P financing platform for Internet finance and traditional financial products of banks ; additionally, foundations are able to realize the long-term income from investment in capital by holding commercial real estate and stock rights of high and new technology enterprises established by transformation of scientific and technological achievements At last, for part of foundations with relative investment and operation experience, the experience of foundations of America universities and colleges can be used for reference to actively explore the investment of alternative assets like private equity and staple commodity, gradually expand investment channels, and realize the optimization operation of investment.

\section{CONCLUSION}

As an important source of educational expenditure financed by China's universities and colleges, education foundations play a crucial role in solving the shortage of construction fund of universities and colleges and promoting the quick development of China's higher education cause. Education foundation of universities and colleges cannot be simply considered as an administrative department in universities and through properly treating the triangle coordination relations that are impelling and restrictive between universities \& colleges in education foundations, government and society, establishing reasonable supervision system by the government and delegating its power to education foundations by universities and colleges to increase the attraction of social assets for education foundations of universities and colleges in order to increase their financing and operation ability, realize the actual functions of raising money for the development of universities and colleges by their education foundations, accelerate the development of China's higher education cause.

\section{REFERENCES}

[1] McDowell. American Foundation Study [M] Shanghai People's Publishing House, 2006,245-246. 
[2] Regulations on the Administration of Foundations. Central People's Government of the People's Republic of China [EB/OL].(2012-112)[2013-11-16]http://www.gov.cn/zwgk/2005-05/23/content_201.htm.

[3] Zou Zhehui Comparison Study for Education Foundations of China and American Universities and Colleges [D]

[4] Wang Xiang and Yang Fan: Engines for Top Universities-How to Run Foundations of Universities in European and America[J] New Fortune,2014(4)

[5] Tao Jidong, Ding Miaomiao, and Liu Yuejun: Study of Incentive Mechanism for University Foundations [J] Journal of China University of Geosciences(Social Science Edition), 2013(6)

[6] Yu Hong: Current Situation, Problems and Solutions of Investment of University Foundations[J]Meitan Higher Education,2012(1)

[7] Ding Anhua and Zhao Yong: Investment and Operation Study of Donated Fund of American Universities[J] Wuhan Finance Monthly,2011(1)

[8] Hou Huawei and Liu Yilun. Problems and Solutions Existing in the Development of Foundations for University Education $[\mathrm{J}]$. Research of Administration of NPOs, 2012,(08).

[9] Buchheit S, Parsons L M . An Experimental Investigation of Accounting Information's Influence on the Individual Giving Process [J] . Journal of Accounting and Public Policy, 2006, (25) .

[10] You Xiangjun . Study of Asymmetry Dependence Relations between China Universities \& Colleges and Education Foundations $[\mathrm{J}]$. China Higher Education Research, 2012,(01)

[11] Li Jie. Dilemma and Optimized Path of Investment of Donated Fund from Universities and Colleges $[\mathrm{J}]$. Jiangsu Higher Education, 2010, (05).

[12] Burton Clark (America), and translator: Wang Chengxu Perspectives on Education--- Eight Disciplinary and Comparative Views [M] Hangzhou: Zhejiang Education Publishing House, 2002.

[13] Meng Dongjun, Chen Lizhen, and Zhang Meifeng: Comparative Study for Education Donation Management between China and American Universities [J], China Higher Education Research, the 7th issue in 2005

[14] Huang Jianhua, You Ruishan, Jing Jianjun and Chijing: Analysis and Thinking of Donation Situation Received by Education Foundation of Tsinghua Universit . [J], Research on Education Tsinghua University, the 1st issue in 2006.

[15] He Meiying: Do a Good Job for Foundation and Promote the Development of Universities [J], Research on Education Tsinghua University, the 1st issue in 2005 .

[16] Wang Renda and Liu Chunda: Develop Foundations of Universities and Facilitate the Donation for University Education $[\mathrm{J}]$, :Journal of Inner Mongolia Normal University, the 11th issue in 2005

[17] Gu Xianlin: The Influence on the Development of Research - oriented Universities in America by Foundations [J], Comparative Education Review, the 12th issue in 2006. 